\title{
Anti-Afrophobia policy shortfall and dilemma in the New Partnership for Africa's Development and South Africa
}

\author{
$P M B E C K E^{l}$
}

\begin{abstract}
Since 1994, South Africa witnessed various xenophobic attacks, the two recent ones leaving over 60 Africans dead in 2008 and 17 in 2015. Xenophobia is an embarrassment to the new South African Government, which is considered the leader of African unity, democracy, good governance and development by some governments in the world. South African and African political leaders have remained indifferent and they have not as yet developed and implemented policies and strategies to address the massacre of Africans in their own continent, hampering prospects of realising the promise of the New Partnership for Africa's Development (NEPAD). This article emphasises a public administration perspective on managing and preventing xenophobia through national and pan-African policies and strategies. It uses migration theory to review South Africa's migration and anti-xenophobia policies and strategies. Through literature review and interviews with the NEPAD Agency, the silence of the continental initiative on xenophobia was confirmed, prompting the need to review the European Union (EU) best practice. The article acknowledges the importance of existing anti-xenophobia strategies in South Africa and advocates for their revival. It also proposes the development of a pan-African framework and structure to deal with racism and xenophobia at the NEPAD continental level.
\end{abstract}

Keywords: xenophobia, Afrophobia, migration, NEPAD, Africa, South Africa

\section{Introduction and Background}

In 2001, South Africa hosted the World Conference against Racism, Racial Discrimination, Xenophobia and Related Intolerance which ended with a Declaration condemning and proposing the fight against such social ills. It is evident that South Africa was chosen to host the conference because of its history, not only of the racial domination during apartheid, but also the scourge of attacks against foreigners (mostly Africans), which were experienced since 1994 portraying an image of a xenophobic nation. Policies and strategies to directly curb such attacks exist but are not fully implemented and monitored.

Xenophobia has a negative impact on the success of the African Union (AU)'s New Partnership for Africa's Development (NEPAD), which is a pledge by African leaders to promote unity and continental development, inclusive of economic growth and respect for human rights and democracy. Section 51 of NEPAD stipulates two conditions for its success: "ownership" of NEPAD by Africans and their "unity in diversity". Evidently, unity cannot coexist with xenophobia. In his statement on the April 2015 xenophobic violence in South Africa, the NEPAD Agency Chief Executive Officer (CEO), Dr Ibrahim Mayaki, emphasised unity of Africans. He declared that the recent spate of violence, looting and

\footnotetext{
${ }^{1}$ Department of Public Administration \& Management, University of South Africa, P.O. Box 392, Unisa, 0003, Pretoria, South Africa, E-mail: mbeckzp@unisa.ac.za
} 
attacks on foreigners is a violation of human rights, life and dignity as well as a betrayal of the core values and principles of pan-Africanism and "Ubuntu" (hospitality and solidarity) (cited in Ajayi, 2015). It is however unfortunate that NEPAD has no official body, policies or strategies to address racism and xenophobia. This was confirmed by Professor Mzobanzi Mboya, the special adviser to NEPAD CEO (telephonic conversation, 26/08/2015).

Most research on xenophobia focusses mainly on its causes and consequences than on management, prevention and control policies and strategies at national and continental scales. This article emphasises the public administration research perspective for two reasons. Firstly, it facilitates the understanding of the incidence of xenophobia in South Africa. The first argument is therefore that xenophobia is rife in South Africa and that although there have been opportunities and potential for South Africa to address xenophobia, existing policies have not been implemented and existing intervention strategies were abandoned. Secondly, the AU through NEPAD has no policies and strategies to address xenophobia at the continent scale. The second argument is that xenophobia is a threat to the unity and development of Africa. Yet, the AU (via NEPAD) has not prioritised measures for addressing xenophobia through a specialised pan-African body nor developed antixenophobia policies and strategies, besides isolated recommendations from the African Peer Review Mechanism (APRM). The two arguments prompted two key recommendations. In the case of South Africa, the existing policies and strategies such as the Roll Back Xenophobia (RBX) Campaign (Braamfontein Statement) and the subsequent National Plan of Action against Racism and Xenophobia should be implemented in full. For the AU, the European Commission best practice on Racism and Tolerance (ECRI) could be used to inform, not only the design of a pan-African anti-racism and xenophobia body, but also to strengthen policies and strategies designed for addressing racism and xenophobia, thereby fostering unity and development of Africa.

\section{Methodology}

The research from which this article is drawn emphasised the need for a public administration perspective on addressing xenophobia through national and pan-African policies and strategies. It concurs with Box (2005) that public administration research analyses how public institutions can influence a better future. The research used a migration theory through qualitative social science methodology. For Castles (2012: 20), migration theory is concerned with the social consequences of trans-national or cross-border human movements. Social science research methodology not only assessed the incidences of xenophobia in South Africa but acknowledged the link between xenophobia and Africa's underdevelopment. Social science research methodology facilitated suggestions on antixenophobia policies and strategies in order to foster unity for the development of Africa. The research adopted the idea of Castles (2012: 8) that social enquiry should be relevant to the pressing issues facing individuals and groups in society, especially in this time whereby a solution to xenophobia seems dubious and does not appear to be on the agenda of the South African or African political leaders.

\section{Theoretical framework}

Three themes justify the theoretical framework adopted for this article. They are social change, identity and diversity as well as the impact of citizenship education, civic and political culture. 


\section{Social change research and development}

Social change research involves assessing the long-term consequences of xenophobia as a particular type of social change (Silbereisen \& Chen, 2010). The article refers to social change as a transition from hospitality and solidarity ("Ubuntu") to hostile and negative values (xenophobia) as direct consequences of movement of people across borders. Reinstating the principles of hospitality and solidarity is therefore crucial. For Inglehart \& Welzel (2005:48), socio-economic development brings pervasive cultural changes in people. Xenophobia is then an expression of unjustified victimisation attitudes by some poor South Africans to vindicate the negative impact of the presence of African immigrants.

\section{Identity and diversity}

Xenophobia in South Africa is illustrative of a struggle of the affirmation of identity. Although the management of local identities within a diversified society is still unachieved, accommodating foreign Africans has been a dilemma of black communities in South Africa. This dilemma describes a phenomenon that Ibanez \& Saenz (2006: 15) refer to as intercultural communication.

\section{Policy on citizenship education, civic and political culture}

Inglehart \& Welzel (2005: 245) argue that a political system is largely determined by political attitudes and value-orientations of its people. Mnyaka (2003) is critical of the importance of citizenship education, civic and political culture in curbing xenophobia in South Africa. The cultural dimension of social change on human development for this article questions the value change, self-expression values and people's increasing priority to act according to their choices (Inglehart \& Welzel, 2005: 2). The authors argue that cultural tradition are remarkably enduring and that they shape the political and economic behaviour of the society (Inglehart \& Welzel, 2005:18-19). Major changes in cultural values at the individual level are reflected in changes at the societal level, according to Inglehart \& Welzel (2005:39).

\section{Research methods and process}

A qualitative methodology included the review of the literature, policies and strategies as the principal data collection technique. Similarly, the analysis of the literature, policies and strategies was the primary data analysis and interpretation technique for the research. Existing policies, strategies and best practice on anti-xenophobia were considered for investigation. Telephonic interviews were conducted with Professor Mzombazi Mboya, the Adviser to the NEPAD CEO, on the role of NEPAD in addressing racism and xenophobia.

Four migration research steps adapted from Castles (2012:14) facilitated the research reported in this article. The first step outlined the issue to be studied and its importance by reviewing the negative impact of xenophobia. The second step consisted of the review and analysis of literature, policies and strategies on xenophobia as core methodology to highlight how South Africa has minimised the incidence of xenophobia and deserted its antixenophobia policies and strategies. The research also observed that NEPAD has no antiracism and xenophobia policies besides few unbinding recommendations through the APRM. The third and fourth steps analysed and reconsidered existing policies and strategies for South Africa and recommended a pan-African body, policies and strategies (informed by 
international best practice) to address racism and xenophobia as a prerequisite for Africa's unity and development.

\section{Xenophobia in South Africa codified}

The ongoing incidences of violent attacks against and killings of Africans, the looting and destruction of property are not recent in South Africa. This section explains xenophobia ("Afrophobia" in the case of South Africa) and briefly describes its incidences, consequences and reasons for its persistence.

For Hatting (2008), the ugly head of xenophobia has been present in South Africa since the 1990s. Meda (2014:72) espouses the same argument that the dislike of foreigners in South Africa developed from the 1990s and spiralled in May 2008. Violent xenophobia has thus become a regular feature of South African life, according to Crush \& Ramachandran (2014). Tracing the first and providing the account of all incidences of xenophobia in South Africa are beyond the scope of this research. However, the 2007 South Africa APRM report already emphasised the "high levels of xenophobic tendencies, especially against foreigners from other African countries” (APRM, 2007: 373).

\section{What is "xenophobia?"}

Etymologically, the term xenophobia originates from two Greek words: xenos (meaning "foreigner" or "stranger") and phobos (meaning "fear") translating to "the fear of foreigners or strangers". For Shabangu \& Mbecke (2008), xenophobia is an unreasonable fear, distrust or hatred of foreigners or strangers perceived as different by a certain population group. They refer to two main elements influencing xenophobia: the presence of a population group considered not part of the society and the proximity to and direct social interaction with noncitizens that impacts citizens' negative attitudes which elicit and sustain hostilities such as mass expulsion, killings and looting as it has been the case in South Africa.

\section{"Afrophobia"}

Xenophobic attacks in South Africa target mostly Africans, thus the use of the term "Afrophobia" to mean the dislike or fear of Africans by South Africans. For Chen (2015), it is sad that South African nationals are welcomed in other African countries yet the same courtesy is not being afforded to other foreign Africans in South Africa. The 2007 APRM also highlights high levels of xenophobia against Africans in South Africa.

\section{Incidences and consequences of Afrophobia}

Crush \& Ramachandran (2014: 1) explain the incidence of xenophobia in South Africa, especially the events of May 2008 through three general categories. "Xenophobia denialism" whereby the denialists reject the idea that xenophobia plays any role in violence against African immigrants. The then president Thabo Mbeki was a denialist. He once stated that he had never met a xenophobic South African and anyone who called South Africans xenophobic was themselves guilty of xenophobia (Crush \& Ramachandran, 2014: 8). The "xenophobia minimalism" meant that the minimalists argue that although xenophobia might exist, it is an epiphenomenon which does not get at the root causes of violence. The "xenophobia realism" describes the realists who suggest that xenophobia is a pervasive phenomenon throughout South Africa and that there is a predisposition to resort to violence on the part of a considerable number of South Africans. 
Crush \& Ramachandran (2014: 6) provide a good brief account of xenophobia incidences in South Africa. They argue that the 2008 attacks were coordinated actions by mobs of South Africans targeting migrants, their properties and causing deaths, injuries and widespread destruction, including the burning alive of a Mozambican man. The estimations of the consequences of the 2008 Afrophobia are tragic; and, they include: 100000 persons displaced, 30000 residential properties destroyed, over 600 people seriously injured and over 60 people murdered. After May 2008, recurring aggressions against African immigrants continued: some 3000 Zimbabweans were forcibly displaced from De Doorns in the Western Cape in 2009; in 2012, 238 incidents were recorded by the United Nations High Commissioner for Refugees (UNHCR), including 120 deaths and 7500 persons displaced; an estimated 120 Somali and 50 Bangladeshi shopkeepers killed in townships; 62 migrants murdered during the first six months of 2013 and around 130 separate episodes of attacks reported. The above account depicts the barbaric incidences of xenophobia in South Africa and its tragic consequences that need to be stopped.

\section{Causes of Afrophobia?}

The causes of Afrophobia are based on perceptions and myths that need to be addressed. Mcdonald, Zinyama, Gay \& De Vletter (1998) argue that the perceptions of South Africans on the causes of migration to South Africa are more myths than realities, resulting in Afrophobia. The authors cite myths such as: "every poor and desperate person on the African continent wants to get into South Africa"; and, "other Africans flood to South Africa to find work or to use health and other social services". Maharaj (2002) argues that xenophobic tendency stigmatises immigrants from other African countries as criminals and people who undermine economic development and take jobs from locals. For Shabangu \& Mbecke (2008), many theories as well as the perception held by some poor, black local residents that black African foreigners compete with them for employment and living space and contribute to the high rate of crime in South Africa explain the main cause of violence and crime against foreign Africans. Mnyaka (2003) and Mpofu-Chimbga (2013) also refer to such unfounded causes as contributing to xenophobia. Mpofu-Chimbga (2013: 22) highlights the strong link between the characteristics of apartheid and issues that seem to lead people to be xenophobic. But these parameters are not explored in this article.

\section{Why Afrophobia persists?}

Three main reasons contribute to the persistence of Afrophobia in South Africa and should be reversed: the non-implementation of policies and strategies addressing xenophobia; the role of the media; and, the absence of citizenship education, civic and political culture. South Africa hosted the World Conference against Racism and Xenophobia in 2001; and, as a UN member, it has acceded to and ratified most international laws that emphasise human rights, including the rights of migrants. The national legislation consists of the Constitution as well as different laws and regulations respecting basic human rights. It is unfortunate that the rights of migrants are not respected in the implementation of the existing laws. Similarly, strategies such as the Roll Back Xenophobia and the National Plan of Action on Racism and Xenophobia exist, but were abandoned leaving the country with no viable option to address Afrophobia. 
Some media play an important role in fuelling the incidences of Afrophobia. Exaggerated figures on immigration broadcast through media can only fuel the anger of some poor, unskilled and unemployed South Africans. For Palmary (2003), the fears that result in hostilities towards foreigners originate in a way from widespread perception that there are "floods" of illegal immigrants coming into South Africa. The author refers to a televised statement by the then National Commissioner of the Police (Jackie Selebi) that there were 8 million illegal immigrants in South Africa in 2002 and the then Minister of Home Affairs who said that there were between 2.5 and 5 million illegal "aliens" in South Africa, costing the State "billions of Rand per year" in 1998 (Palmary, 2002: 5). For Crush (2001: 16), public attitudes have been fanned by highly emotional media images that portray South Africa being "flooded" or "overrun" by undocumented migrants from the rest of Africa. Contrary to these exaggerations, Gigaba (2015) quoted the 2011 Census that there were only 2.2 million foreigners residing in South Africa (approximately 4\% of the population, compared to $12 \%$ in the UK and France, $20 \%$ in Canada, and $27 \%$ in Switzerland). He admitted that international migration is an area which is constantly beset by myth and distortion.

The media has failed to educate South Africans on immigration issues, on the rights of foreigners and on the myths and perceptions; and, the same is true for government. According to Crush (2001: 17), a 1998 survey of human rights awareness conducted by the Community Agency for Social Enquiry (CASE) revealed that knowledge of the existence of the Bill of Rights in the Constitution is low among the South African population. There are some initiatives that have been implemented for awareness but their impact is trivial, considering that they are punctuated only during the incidences of xenophobia.

\section{Anti-xenophobia policies and strategies review}

South Africa has no direct anti-xenophobia policies although it has a progressive legislation on numerous other issues (Shabangu \& Mbecke, 2008). Such a vacuum has resulted in challenges in addressing Afrophobia. The AU shares the same dilemma as it has no policies and strategies designed for addressing racism and xenophobia. This section assesses existing policies and strategies that could have assisted the South African government to address Afrophobia. It also reviews international best on anti-racism, discrimination and xenophobia to inform the recommendations to the AU.

\section{The Universal Declaration of Human Rights}

Although not really framed as a direct anti-xenophobia policy, the Universal Declaration of Human Rights (UNDH) is an international tool that guarantees the basic rights of all individuals. Proclaimed on 10 December 1948, the UNDH emphasises the recognition of the inherent dignity as well as equal and inalienable rights of all members of the human family as the foundation of freedom, justice and peace in the world. Three articles of the UNDH are essential in dealing with xenophobia. Article 13(1) stipulates that "everyone has the right to freedom of movement and residence within the borders of each state" and 13(2) that: "everyone has the right to leave any country, including his own, and to return to his country. Article 14(1): specifies that "everyone has the right to seek and to enjoy in other countries asylum from persecution". Article 17(1) and (2) stipulates that "everyone has the right to own property alone and in association with others and no one shall be arbitrarily deprived of his property". All these provisions are known to the South African Government and are included in laws like the Refugee Act. However, they are not implemented, monitored and enforced 
with regard to dealing with Afrophobia. For the AU, there is no policy and strategy that has been developed at the NEPAD level to practically address racism and xenophobia.

\section{Constitution of the Republic of South Africa}

The Constitution guarantees basic rights and freedom to everyone. Basic rights such as freedom of speech, freedom of movement, legal protection, police protection and access to services are however not afforded to many South Africans let alone foreigners

\section{Immigration Act, 2002}

The Immigration Act provides for the regulation of admissions of persons to, their residence in, and their departure from the Republic; and, for matters connected therewith. The Act ensures that push factors of illegal immigration may be addressed in cooperation with other Departments and the foreign states concerned; that immigration control is performed within the highest applicable standards of human rights protection; and, importantly that xenophobia is prevented and countered both within Government and civil society. The main complaints are that foreigners are not well treated by the Department of Home Affairs itself and/or officials therein.

\section{The Refugee Act, 1998}

The Refugee Act was enacted to give effect to relevant international legal instruments, such as the 1951 Convention Relating to Status of Refugees, the 1967 Protocol Relating to the Status of Refugees and the 1969 Organisation of African Unity Convention Governing the Specific Aspects of Refugee problems in Africa. It provides for the reception of asylum seekers into South Africa and it regulates applications for and recognition of refugee status. The Act was supposed to facilitate the treatment of refugees in accordance with standards and principles of the international law. However, the experience of asylum seekers and refugee is not appreciated by the Human Rights activists and organisations.

\section{European Commission against Racism and Intolerance (ECRI): Best practice}

ECRI was established in 1993 as a mechanism consisting of measures to combat racism, xenophobia, antisemitism and intolerance in Europe in order to protect and promote human rights. It is a human rights body of the Council of Europe which monitors problems of racism, xenophobia, antisemitism, intolerance and discrimination, along "race", national/ethnic origin, colour, citizenship, religion and language divides. ECRI promotes the creation and strengthening of bodies, development of standards, guidelines and recommendations in addressing all forms of racism, xenophobia, antisemitism and intolerance in Europe (ECRI, 2006). It provides General Policy Recommendations and platforms for the exchange of good practices regarding racism, xenophobia, antisemitism and intolerance. The Council of Europe supports ECRI in carrying out its work in co-operation with national authorities, institutions and civil society (ECRI, 2006: 5). However, ECRI cannot claim full success in curbing racism and xenophobia. Yet, it is a good initiative that the $\mathrm{AU}(\mathrm{NEPAD})$ can learn from in its strife to prevent and manage racism and xenophobia, thus promoting the unity and development of Africa. Conclusion and recommendations

The literature on the causes, consequences and persistence of xenophobia is rich. However, the public administration-based approach on policies and strategies to address Afrophobia in South Africa and racism and xenophobia in Africa is deficient. Thus, this research suggests 
that the Constitution of South Africa, the Immigration Act and the Refugee Act are important in promoting and sustaining the rights of migrants if effectively implemented. Strategies such as the Roll Back Xenophobia and the National Plan of Action are relevant and valid tools in addressing Afrophobia in South Africa. Developing a pan-African body, policies and strategies against racism and xenophobia, including pragmatic recommendations on anti-racism and xenophobia in the APRM.

South Africa's Anti-Afrophobia strategies, the Roll Back Xenophobia (RBX) Campaign: In 1997, the South African Human Rights Commission (SAHRC) identified xenophobia as a major source of concern to human rights and democracy in South Africa. It then partnered with the UNHCR and the National Consortium on Refugee Affairs (NCRA) to develop a public and media education programme known as the Roll Back Xenophobia which was launched on 15 October 1998. The key message of the RBX campaign was that: "an irrational prejudice and hostility towards non-nationals is not acceptable under any circumstances”. The RBX's Braamfontein Statement is still relevant (see Box 1 below).

\section{Box 1: Roll Back Xenophobia - Braamfontein Statement}

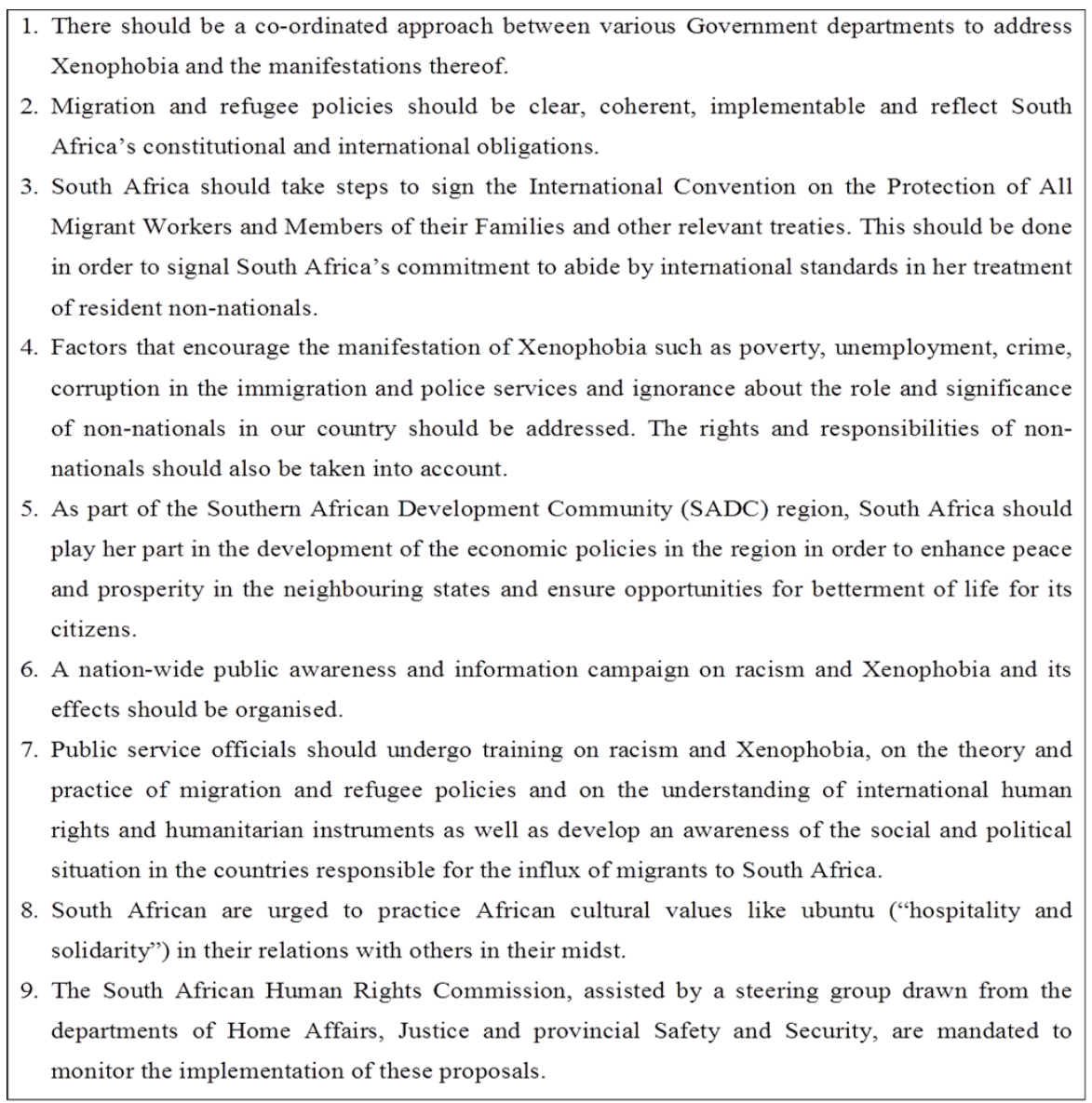

\section{Source: South African Human Rights Commission}

The Braamfontein Statement was a key strategy for addressing xenophobia. It is unfortunate that government never devoted itself to its implementation and monitoring; thus, this article advocates for its resumption. There are some Roll Back Xenophobia activities that are happening in silos that need to be coordinated by Government. For instance, a Call for Expressions of Interest was issued by the Foundation for Human Rights in partnership with the Department of Justice \& Constitutional Development on 29 April 2015 to raise 
awareness and knowledge of the Constitution amongst vulnerable groups as a response to the resurgence of Afrophobia.

The National Plan of Action on Racism and Xenophobia emphasised the need for public education on racism and xenophobia and clarified the role of civil servants, migrants and media in fostering tolerance and better understanding of the reasons for the presence of migrants and promoting creative use of the skills brought by migrants to South Africa. Such a plan has never been implemented and should be reconsidered.

The media can play a positive role in educating the public on migration issues the same way it has contributed in fuelling the incidences of Afrophobia. Part of the RBX campaign was to work with the media in an attempt to facilitate accurate, factual and truthful coverage of refugees, asylum seekers and migrants. Such an initiative is still valid and should be revived. For Mnyaka (2003), the reduction of inflammatory statements by Government representatives and the media can assist in reducing xenophobia.

Citizen education, civic and political culture: Accepting inalienable human rights as outlined in the UDHR and the Constitution of South Africa at individual and societal levels is essential for xenophobia (Shabangu \& Mbecke, 2008). For Mnyaka (2003), educating the unemployed, the youth and workers on xenophobia is crucial in South Africa. Mcdonald, Zinyama, Gay \& De Vletter (1998) emphasise the importance of education in addressing the myths and clarifying the realities about cross-border migration to South Africa. In addressing xenophobia, citizenship education must emphasise the relationship between individuals and groups from different backgrounds and cultures (Kiwan, 2008). Interactions with others from a diversity of backgrounds reduces prejudices and undermines negative stereotypes is appropriate.

Anti-racism and xenophobia strategies in NEPAD: Two strategic considerations are important to put the AU at the forefront of the fight against racism and xenophobia: to develop a panAfrican body against racism and xenophobia and to include practical anti-racism and xenophobia recommendations as part of the APRM.

A pan-African framework against racism and xenophobia: NEPAD acknowledges that xenophobia is not only rife in South Africa, but that it is also an African predicament that needs to be curbed. Using ECRI best practice, the AU needs to have a body and structure to deal with racism and xenophobia. Although not yet officially announced, NEPAD is coordinating a think tank to develop a pan-African concept document on addressing xenophobia in Africa (telephonic conversation with Professor Mzobanzi Mboya, 26/08/2015). It is advisable that such initiative seeks the support of AU structures in order to develop a binding pan-African system considering the proposed framework (see figure 1).

Review of the APRM to include anti-racism and xenophobia as a full theme: The 2007 South Africa APRM report recommended amongst other things that South Africa should: "find better-informed measures for combating the growing problem of xenophobia, such as programmes of civic education (Department of Home Affairs; Department of Education; civil society actors)"; and, "strengthen anti-xenophobic institutions such as the CounterXenophobia and Counter-Corruption Unit (Counter-Xenophobia and Counter-Corruption Unit; Parliament; Judiciary)" (Ajayi, 2015). These recommendations are unfortunately irrelevant as they are not based on existing pan-African policies. It is therefore important to review the APRM to include clear recommendations on anti-racism and xenophobia strategies responding to the vision, mission and principles of NEPAD. 


\section{Figure 1: The Pan-African Committee against Racism and Xenophobia (PACRX)}

\begin{tabular}{|c|c|c|c|}
\hline \multicolumn{4}{|c|}{$\begin{array}{l}\text { The Pan-African Committee against Racism and Xenophobia (PACRX) is a NEPAD advisory and } \\
\text { monitoring body established by the AU Heads of State and Government to prevent, manage and } \\
\text { control racism and xenophobia and their impact on Africa's development. }\end{array}$} \\
\hline Vision: & \multicolumn{3}{|c|}{ PACRX envisions a developed and prosper Africa free of racism and xenophobia } \\
\hline Mission & \multicolumn{3}{|c|}{$\begin{array}{l}\text { To provide strategies to prevent, manage and control racism and xenophobia and to } \\
\text { protect and promote human rights in Africa }\end{array}$} \\
\hline Objectives & \multicolumn{3}{|c|}{$\begin{array}{l}\text { 1. Advise countries on establishing national legislations, strategies and bodies to } \\
\text { prevent, manage and control racism and xenophobia } \\
\text { 2. Provide specific recommendations on preventing, managing and controlling } \\
\text { racism and xenophobia through the APRM } \\
\text { 3. Share information, international legal instruments and best practices on } \\
\text { preventing, managing and controlling racism and xenophobia } \\
\text { 4. Monitor and evaluate progress of each member state on preventing, managing } \\
\text { and controlling racism and xenophobia through the APRM }\end{array}$} \\
\hline \multicolumn{4}{|c|}{ Advisory, monitoring and evaluation tasks of the PACRX are (explained below): } \\
\hline \multicolumn{2}{|l|}{ Task } & Outcome & Responsibility \\
\hline \multicolumn{2}{|c|}{$\begin{array}{l}\text { Develop/implement NEPAD anti-racism } \\
\text { and xenophobia framework }\end{array}$} & $\begin{array}{l}\text { Pan-African anti-racism and } \\
\text { xenophobia framework }\end{array}$ & PACRX \\
\hline \multicolumn{2}{|c|}{$\begin{array}{l}\text { Review the APRM to include anti-racism } \\
\text { and xenophobia indicators }\end{array}$} & $\begin{array}{l}\text { Reviewed APRM including } \\
\text { anti-racism and xenophobia } \\
\text { indicators }\end{array}$ & PACRX \\
\hline \multicolumn{2}{|c|}{$\begin{array}{l}\text { Develop guidelines on national anti- } \\
\text { racism and xenophobia legislations, } \\
\text { strategies and bodies }\end{array}$} & $\begin{array}{l}\text { Guidelines on national anti- } \\
\text { racism and xenophobia } \\
\text { legislations, strategies and } \\
\text { bodies }\end{array}$ & PACRX \\
\hline \multicolumn{2}{|c|}{$\begin{array}{l}\text { Facilitate the development of national } \\
\text { anti-racism and xenophobia legislations, } \\
\text { strategies and bodies (recommendations, } \\
\text { technical support) }\end{array}$} & $\begin{array}{l}\text { National anti-racism and } \\
\text { xenophobia legislations, } \\
\text { strategies and bodies for each } \\
\text { member state }\end{array}$ & $\begin{array}{l}\text { PACRX } \\
\text { Member states }\end{array}$ \\
\hline \multicolumn{2}{|c|}{$\begin{array}{l}\text { Provide training and capacity building on } \\
\text { preventing, managing and controlling } \\
\text { racism and xenophobia }\end{array}$} & $\begin{array}{l}\text { Officials from member states } \\
\text { are trained }\end{array}$ & PACRX \\
\hline \multicolumn{2}{|c|}{$\begin{array}{l}\text { Monitor and evaluate the progress made } \\
\text { by each member state on preventing, } \\
\text { managing and controlling racism and } \\
\text { xenophobia }\end{array}$} & $\begin{array}{l}\text { APRM reports focussing on } \\
\text { anti-racism and xenophobia } \\
\text { monitoring and evaluation } \\
\text { indicators }\end{array}$ & PACRX \\
\hline
\end{tabular}

\section{Source: Author}

The APRM is a mutually agreed self-monitoring mechanism, voluntarily adopted by the AU member states to promote and re-enforce high standards of governance. The mandate of the APRM is to ensure that the policies and practices of participating countries conform to the agreed values in the following democracy and political governance, economic governance, corporate governance and socio-economic development. Although there is no conditionality attached to the APRM, democracy and good political governance focus seeks to ensure that the constitutions of member states reflect the democratic ethos, provide accountable governance and that political representation is promoted, allowing all citizens to participate in the political process in a free and fair political environment. This focus must therefore be reviewed to elevate the fight against racism and xenophobia to the level of a full theme. 


\section{References}

African Peer Review Mechanism (APRM), 2007. Country Report No. 5: Republic of South Africa. Midrand: APR Secretariat.

Ajayi, A. 2015. NEPAD Agency Statement on Xenophobic Violence in South Africa. URL: http://www.nepad.org/ceo039s-office/news/3627/nepad-agency-statementxenophobic-violence-south-africa [Accessed: 20 August 2015].

Castles, S. 2012. Understanding the relationship between methodology and methods. In Vargas-Silva, C. (ed.). Handbook of Research Methods in Migration. Cheltenham: Edward Elgar Publishing Limited, pp.7-25.

Chen, L. 2015. Regressive Effects of Xenophobia to South Africa's Economic Growth. URL: http://www.leadershiponline.co.za/articles/xenophobia-14276.html [Accessed: 13 July 2015].

Crush, J. 2001. Immigration, Xenophobia and Human Rights in South Africa. Cape Town: Southern African Migration Project/South African Human Rights Commission.

Crush, J. \& Ramachandran, S. 2014. Xenophobic Violence in South Africa: Denialism, Minimalism, Realism. Migration Policy Series No. 66. Cape Town: Southern African Migration Project.

European Commission against Racism and Tolerance (ECRI), 2006. Examples of Good Practices: Specialised Bodies to Combat Racism, Xenophobia, Antisemitism and Intolerance at National Level. Strasbourg: Council of Europe.

Gigaba, M. 2015. Address at "Youth and Migration Dialogue", 14 August 2015, Pretoria.

Hattingh, S. 2008. Xenophobia, Neo-liberalism, and NEPAD: The End of African Unity? URL: http://mrzine.monthlyreview.org/2008/hattingh050608.html [Accessed: 26 April 2015].

Ibanez, B.P. \& Saenz MC. L. (eds.). 2006. Interculturalism: Between Identity and Diversity. Bern: Peter Lang.

Inglehart, R. \& Welzel, C. 2005. Modernisation, Cultural Change and Democracy: The Human Development Sequence. New York: Cambridge University Press.

Kiwan, D. 2008. Education for Inclusive Citizenship. Oxon: Routledge.

Maharaj, B. 2001. Economic refugees in post-apartheid South Africa - Assets or liabilities? Implications for progressive migration policies. GeoJournal, 12: 47-57.

Mcdonald, D., Zinyama, L., Gay, J. \& De Vletter, F. 1998. Challenging Xenophobia: Myths E Realities about Cross-Border Migration in Southern Africa. Cape Town: Southern African Migration Project.

Meda, L. 2014. The mist that they declared to be over is still around: Xenophobic experiences of refugee children living at a community centre in South Africa. Child Abuse Research - A South African Journal, 15(2): 72-82.

Mnyaka, M.M.N. 2003. Xenophobia as a response to foreigners in post-apartheid South Africa and post-exilic Israel: A comparative critique in the light of the gospel and Ubuntu ethical principles. Doctoral Thesis submitted to the University of South Africa, Pretoria. 
Mpofu-Chimbga, W.W. 2013. The Role of Secondary Schools in Averting Xenophobia in South Africa. Doctoral Thesis submitted to the University of South Africa, Pretoria.

African Union (AU), 2001. The New Partnership for Africa's Development. Abuja: AU.

Palmary, I. 2002. Refugees, Safety and Xenophobia in South African Cities: The Role of Local Government. Braamfontein: Centre for the Study of Violence and Reconciliation.

Republic of South Africa (RSA), 1996. Constitution. Pretoria: Government Printers.

Republic of South Africa (RSA), 1998. Refugee Act. Pretoria: Government Printers.

Republic of South Africa (RSA), 2002. Immigration Act. Pretoria: Government Printers.

Silbereisen, R.K. \& Chen, X. (eds.). 2010. Social Change and Human Development: Concepts and Results. London: Sage Publications Limited.

Shabangu, T. \& Mbecke, P. 2008. Practical Guide for Defending the Rights of Refugee Children and Refugee Unaccompanied Minors in South Africa: Policy Review, Process, Procedures Eซ Practical Experience. Johannesburg: Refugee Children's Project.

South African Human Rights Commission (SAHRC), 1998. Roll Back Xenophobia Braamfontein Statement $\mathcal{E}^{2}$ National Plan of Action. Racism $\mathcal{E}^{3}$ Xenophobia: A violation of Human Rights. Houghton: SAHRC. 